Michael Ashby*

University College London

Patricia Ashby ${ }^{* *}$

University of Westminster
UDK $811.111^{\prime} 342.9$

DOI: 10.4312/linguistica.57.1.29-43

\title{
UNRULY INTONATION
}

\section{INTRODUCTION}

Learning the intonation of English as a foreign language involves considerably more than becoming familiar with, and reproducing, the physical form of English pitch-patterns. It is also necessary to develop some understanding of the systems of choices in English intonation, so that the learner can select suitable intonations in spontaneous speech or when reading aloud. Influential accounts of English intonation for EFL (e.g. Wells 2006) present the choices in tonality, tonicity and tone as being extensively governed by grammatical and pragmatic regularities which can be taught and learned.

But in this paper we call into question the value of 'rules' concerning intonation to the learner of English. Are there predictive rules of sufficient generality and power to make them worth learning explicitly, or would learners' time be better spent on habit-forming drills of common patterns? We inquire whether widely taught rules are universally valid, or work well only with materials artificially contrived to exhibit them.

The utility of rules has been assessed experimentally using a written dialogue of a type suitable as an examination test passage for advanced students. Three expert judges provided intonation notations of plausible treatments of the passage. A comparative analysis of the three versions reveals a very high degree of agreement among the judges, enabling a consensus version to be determined. The features of this version are then evaluated against supposedly well-established principles of English intonation, to determine how successfully those principles predict the outcomes actually observed. It is shown that in many cases the judges are in agreement over the selection of a particular pattern even though no established rule or principle seems to account for the choice they have made.

The experiment is not unlike what was suggested by House (1987: 365): 'perhaps a more objective measure [of the effectiveness of a set of 'rules' for intonation] could be obtained by inviting a number of competent speakers to record an identical text in near-identical circumstances and using their range of prosodic choices as a yardstick' - except that in the present case the 'competent speakers' were able to notate their own intonation choices directly, rendering the recording stage redundant.

* m.ashby@ucl.ac.uk

**ashbyp@westminster.ac.uk 


\section{METHOD AND MATERIALS}

A dialogue of approximately 160 words was devised. No attempt was made to disguise the contrived style of the dialogue, which, as already mentioned, is of a kind suitable for use as an examination transcription passage by advanced students of English phonetics and phonology. The dialogue is given below.

A: Where's that report for the newsletter you were supposed to be letting me have by the end of the month?

B: Well, admittedly today's the 31st, but I've only got a bit of final editing to do-and it is only breakfast time.

A: The 31st? Of April?

B: Ah. Good point. I was going by my watch.

A: What's the use of having half a ton of stainless steel world-time chronometer strapped round your wrist if it doesn't know how many days there are in the month?

B: Be fair. It doesn't claim to do months. You have to change it manually. I remembered to do it in February.

A: I should hope so, or you'd be half a week out by now. Anyway, stop fiddling with the stupid thing and switch your laptop on. I only need a couple of paragraphs.

B: Hey, hang on! Look! You didn't actually specify BST. It's still the 30th in Alaska, and I've got an hour to spare.

Possible prosodic treatments of the dialogue were notated by one of the authors (shown as $E$ in what follows), and independently by two judges, $J 1$ and $J 2$, who are two colleagues with particular expertise in English intonation. ${ }^{1}$ All used a framework of analysis and notation system similar to those of Wells (2006). All three provided judgements of tonality (division into intonational phrases ${ }^{2}$ (IPs)), tonicity (location of nuclear accents), and tone (pitch treatment of nuclei). Both $E$ and $J 1$ also marked the onset and type of head in each IP. The three notated versions are reproduced in full in the appendix to this paper.

As expected, the three versions show a very high degree of similarity. The convergence among the versions will be considered separately under the headings of tonality, tonicity and tone.

\section{RESULTS: AGREEMENT IN TONALITY}

The numbers of IPs used in the versions of the passage were: $E 29, J 128, J 229$. Of these, 20 are terminated by a turn-end, or, if within the turn, by the major punctuation marks period (.), dash (-), question mark (?), or exclamation mark. These cases are not considered further.

1 We are grateful to Jill House and John Maidment for their willing collaboration.

2 Wells (2006) writes intonation phrase, though intonational phrase (with -al) is more usual in the literature. 
The correspondences in the locations of the remaining IP boundaries in the three versions are summarized in Table 1. A black circle indicates the presence of an IP boundary at a certain point in the text, and a white circle indicates its absence. There are seven possible patterns of correspondence: a given IP boundary may be present in all three versions (row $a$ of the table), in any selection of two versions but not the third (rows $c, d$ and $g$ ), or in one version only (rows $b, e$, and $f$ ). The horizontal bars indicate the relative frequency of each case, with the actual count, $N$, shown in the final column.

Table 1: Correspondences in locations of IP boundaries

\begin{tabular}{|l|c|c|c|c|c|}
\cline { 2 - 6 } \multicolumn{1}{c|}{} & E & J1 & J2 & & N \\
\hline a & $\bullet$ & $\bullet$ & $\bullet$ & & 8 \\
\hline b & $\bullet$ & $\circ$ & $\circ$ & & 1 \\
\hline c & $\bullet$ & $\bullet$ & $\circ$ & & 0 \\
\hline d & $\bullet$ & $\circ$ & $\bullet$ & & 0 \\
\hline e & $\circ$ & $\bullet$ & $\circ$ & & 0 \\
\hline f & $\circ$ & $\circ$ & $\bullet$ & & 1 \\
\hline g & $\circ$ & $\bullet$ & $\bullet$ & & 0 \\
\hline
\end{tabular}

It is evident that the three versions agree very closely. The average number of potentially variable IP boundary locations is 8.66 , and of these 8 are found in the same location across all three versions, representing a $92.4 \%$ agreement.

Of the 8 IP boundaries which appear in all three versions (row $a$ ), 5 correspond to a comma in the text. The correspondence between punctuation and IP division is not quite perfect, however, since the text does contain one example of a comma which is not treated as an IP boundary in any of the three versions (in Well, admittedly today's the 31st).

All versions agree in inserting IP boundaries at three locations which are not marked by punctuation:

... chronometer strapped round your wrist $\mid$ if it doesn't know how ...

... fiddling with the stupid thing $\mid$ and switch your laptop on ...

It's still the $30^{\text {th }} \mid$ in Alaska ...

There are just two cases in Table 1 (rows $b$ and $f$ ) where one version inserts an IP boundary which is not used by the others. In one of these cases, the extra boundary is probably no more than a notational variant: $E$ has half a lweek out by /now, with two nuclear tones ('fall plus rise') in a single IP, while $J 2$ notates the same pattern as half $a$ lweek out $\mid$ by $/$ now. The other case is a boundary inserted by $E$ after newsletter in the first line of the dialogue. $E$ confirms this division is optional, and that the single-IP treatment given by $J 1$ and $J 2$ may indeed be preferable. 


\section{RESULTS: AGREEMENT IN TONICITY}

The total number of nuclear-tone marks in all three versions taken together is 87 . This is equal to the total number of IPs identified $(29+28+29)$, plus one more because $E$ marked two nuclear tones ('fall plus rise') in one IP. The correspondences among the choices for location are summarized in Table 2, where the indications are used in the same manner as in Table 1. Note that the bars (and the numbers in $N$ ) represent the number of distinct choices, not the number of tokens. Thus, the 24 choices of nucleus position in row $a$ (those used in all three versions) account for 72 tokens of nucleus allocation, since each choice is repeated in all three versions. In the same way, each choice of the types shown in rows $c, d$, or $g$ will contribute 2 to the count of nuclear tone marks, since it occurs in 2 of the 3 versions.

Table 2: Correspondences in location of nuclear syllables

\begin{tabular}{|l|c|c|c|c|c|}
\cline { 2 - 6 } \multicolumn{1}{c|}{} & E & J1 & J2 & & N \\
\hline a & $\bullet$ & $\bullet$ & $\bullet$ & & 24 \\
\hline b & $\bullet$ & $\circ$ & $\circ$ & & 1 \\
\hline c & $\bullet$ & $\bullet$ & 0 & & 1 \\
\hline d & $\bullet$ & $\circ$ & $\bullet$ & & \\
\hline e & $\circ$ & $\bullet$ & $\circ$ & & 1 \\
\hline f & $\circ$ & $\circ$ & $\bullet$ & & 1 \\
\hline g & $\circ$ & $\bullet$ & $\bullet$ & & 2 \\
\hline
\end{tabular}

Again, it is evident that the three versions agree closely. Twenty-four nuclear syllables are in the same positions for all three versions. Since the mean number of nuclear syllables is 28.66 , we may say that $83.7 \%$ of the tonicity choices follow the same pattern.

At the same time, and again as in the case of tonality, there are some small differences between versions. As Table 2 shows, each of $E, J 1$ and $J 2$ makes at least one tonicity choice which the others do not follow, and there are also cases of agreement between two of them, to the exclusion of the third.

\section{RESULTS: AGREEMENT OF TONE}

One might make a case for recognising some measure of general similarity of tone in corresponding IPs without perfect alignment, but in the interests of objectivity agreements have only been counted in those cases where tonicity also corresponds exactly. From Table 2 it is evident that (counting both 2- and 3-way agreements) there are 29 instances of corresponding tonicity, and thus there are 29 opportunities for matching tone choices to be made. Table 3 shows the 2 - and 3 -way tone agreements found in the data. 
Table 3: Correspondences in tone choice

\begin{tabular}{|l|c|c|c|l|c|}
\cline { 2 - 7 } \multicolumn{1}{c|}{} & E & J1 & J2 & & N \\
\hline $\mathrm{a}$ & $\bullet$ & $\bullet$ & $\bullet$ & & 18 \\
\hline $\mathrm{b}$ & $\bullet$ & 0 & 0 & & \\
\hline $\mathrm{c}$ & $\bullet$ & $\bullet$ & 0 & & \\
\hline $\mathrm{d}$ & $\bullet$ & 0 & $\bullet$ & & \\
\hline $\mathrm{e}$ & $\circ$ & $\bullet$ & 0 & & \\
\hline $\mathrm{f}$ & $\circ$ & 0 & $\bullet$ & & 6 \\
\hline $\mathrm{g}$ & $\circ$ & $\bullet$ & $\bullet$ & & \\
\hline
\end{tabular}

Note: Rows $b, e$ and $f$ are retained, but are shown greyed out since it is logically impossible for correspondences to occur in them.

Table 3 indicates that for 3-way agreements, we find 18 out of a possible 24, an agreement rate of $75 \%$. Overall, of the 29 possible 2- or 3-way tone agreements in the data, 29 are in fact found.

\section{CONSENSUS}

It is plain from this analysis that the test passage was successful in eliciting a very high degree of inter-observer agreement. Whether we consider tonality, tonicity or tone choices, the agreement in every case takes the form of (i) a large proportion of choices - more than $83 \%$ - made in exactly the same fashion by all observers, and (ii) a smaller number of discrepant choices, at least some of which turn out on examination to be little more than notational differences or optional variants. It is therefore possible to construct a consensus version, in which the majority of choices incorporated are supported by all three versions, and all the choices by at least two. The only instance where such consensus fails is the IP It doesn't claim to do months, for which there is no agreement over tonicity.

The consensus version is as follows:

A: Where's that report for the Inewsletter you were supposed to be letting me have by the end of the month? |

B: Well, admittedly today's the $3 \bigvee \underline{1 s t}$, | but I've only got a bit of final Vediting to do $\mid$ - and it is only Vbreakfast time. |

A: The $3 / \underline{1 s t}$ ? | Of / April? |

B: $\underline{\text { Ah. }}$. Good |point. | I was going by my lwatch. |

A: What's the use of having half a ton of stainless steel world-time chroVnometer strapped round your wrist | if it doesn't know how many ldays there are in the month? | 
B: Be /fair. | Htoesn't claim to do months (no consensus). | You have to change it Imanually. | I remembered to do it in VFebruary. |

A: I should hope Iso, | or you'd be half a lweek out by /now. | |Lnyway, | stop Vfid-

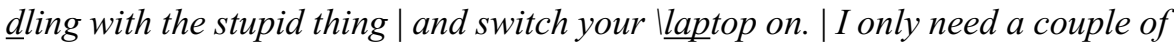
Vparagraphs. |

B: $\underline{\text { Hey, }}$ | hang /on! $\mid \underline{\text { Look! }}$ | You didn't actually specify BS $\mid \underline{T}$. | It's still the $|\underline{30 t h}|$ in AVlaska, | and I've got an hour to lspare. |

It seems clear that such a degree of agreement could only arise from shared 'knowledge' among the observers, and presumably the knowledge they share must be of prosodic 'rules'. Accounts of English intonation attempt to establish and teach such rules, so it is reasonable to ask, in relation to each of the regularities, which 'rule' it exemplifies.

\section{ASSESSING RULES FOR TONALITY}

A number of conclusions can be offered on the basis of the findings concerning tonality. The first observations concern punctuation. Though warnings about the 'notorious' inconsistency of punctuation practices are regularly issued (Tench 1996: 21), the simple fact, amply illustrated by the present experiment, is that punctuation is an excellent guide to IP division. As House says (1987: 365), ' $\ldots$ the availability of punctuation to guide intonational phrasing is not trivial; real speakers certainly use it, existing text-tospeech systems rely heavily on it'. In reading aloud from a prepared script, or in supplying intonation for a written text, the learner's task is precisely that of text-to-speech conversion (TTS).

Yet intonation handbooks appear to contain very limited guidance about punctuation. Wells (2006: 60) has some discussion of the exclamation mark, and the practical guide to making intonation mark-ups (pages 251-258) contains a few remarks. But the learner actually needs an explicit step-by-step procedure. A comprehensive account of the history and current status of the relationship between the comma and IP division is given by Cruttenden (1991), and from that analysis it is plain that an excellent heuristic for the learner is to introduce an IP division at every written comma. The only example in the present text of a comma which does not signal an obligatory IP division is that in Well, admittedly today's the 31st. In this connection we may note (i) that to introduce an IP division at this point would not be a major defect, and (ii) that Well, is such a ubiquitous sentence-opener, especially in spoken texts, ${ }^{3}$ that a learner might profitably be told that it is generally written with a comma though commonly spoken without a corresponding IP division.

In our experience, to sidestep the punctuation question, and ask learners to read from, or to transcribe, unpunctuated text - as has sometimes been tried (Tench 1996: 52) - is

3 A search in the British National Corpus (BNC) for "well," reveals that stretches beginning this way are almost 3.5 times more frequent in spoken texts than in written. The BNC was queried using the BNCweb interface at http://www.natcorp.ox.ac.uk/. 
to set them a completely irrelevant linguistic puzzle (cf. Crystal 1976: 9). Reading aloud is reading from text - and text is punctuated.

Further observations concern the relationship between IP and clause. All intonation handbooks point out a general correspondence between the IP and clause, and schemes of varying degrees of complexity have been worked out which predict intonational phrasing in a text if provided with a syntactic parsing (Crystal 1975; Alternberg 1987). But before the learner invests time in becoming familiar with such a scheme, there are several issues to be addressed. For a start, the worth of this kind of approach depends not on its overall success rate (which may appear very high), but on what could be called its added value - that is, its success rate in those cases where a learner will fail when using a simple heuristic (such as following the guidance provided by punctuation). Furthermore, this must be considered in conjunction with the text frequency of the relevant structures in the types of discourse with which the learner is dealing (since there is plainly little profit in learning to deal with clause types which are only rarely encountered).

A specific case is the example of relative clauses. Intonation handbooks invariably dwell on the distinction between 'defining' and 'non-defining' relative clauses, and the accompanying prosodic differences (Wells 2006: 202-203; Tench 1996: 40-41). But it can be pointed out that examples such as my sister | who lives in Canada (Wells) or my brother | who lives in Nairobi (Tench) belong predominantly to written language anyway. As a simple test of this claim, a search was conducted in the BNC for the sequence ", who lives". ${ }^{4}$ Only three hits ( 0.29 instances per million words) were found in spoken texts, and only one of the three appears to introduce a non-restrictive relative clause. By contrast, 269 hits (3.06 instances per million words) were found in written texts, and most are clearly at the beginning of non-restrictive clauses. If, as this suggests, non-restrictive clauses are predominantly a feature of the written language, it is simpler to regard the prosodic treatment accorded to them as a result of reading aloud the way they are conventionally written rather than the reverse. In fact, the treatment follows straightforwardly from taking each comma as marking an IP division.

The test passage used in this study contains one example of a relative clause: you were supposed to be letting me have by the end of the month. The consensus treatment, supported by two judges, $J 1$ and $J 2$, and acknowledged as entirely plausible by $E$, places this in the same IP as what precedes: Where's that report for the Inewsletter you were supposed to be letting me have by the end of the month?

If we ask what 'rules' might lead to this treatment, we encounter some considerable difficulty. Suppose that $J 1$ and $J 2$ choose to treat the relative clause as 'defining', and that for this reason they integrate it into the same IP as its antecedent, newsletter. This might possibly account for the consensus tonality choice - although the outcome appears to go against at least two other principles. First, the resulting IP is unusually

4 We are grateful to an anonymous reviewer for suggesting that we test this claim against corpus data. As that reviewer correctly notes, the frequency of "who lives" (no comma) is approximately equal in written and spoken material in the BNC. The imbalance regarded as significant here is found only when the comma is included as part of the search string: ", who lives". 
long ( $J 1$ actually added a comment on the length of the resulting tail), and secondly that report for the newsletter appears to be a relatively 'heavy' noun phrase (Wells 2006: 198), and thus a candidate to be given its own IP.

Besides, the distinction between 'defining' and 'non-defining' (or 'restrictive' and 'non-restrictive') is itself problematic once a wider range of more realistic examples is considered (Huddleston/Pullum 2005: 188). Although the consensus tonality choice may seem to suggest that the clause in question is being treated as 'defining', the distinction does not appear to be particularly relevant. As far as can be gathered from the context, any of that report, that report for the newsletter, that report for the newsletter you were supposed to be letting me have, or that report for the newsletter you were supposed to be letting me have by the end of the month would identify the likely referent equally well. The purpose of the clause you were supposed to be letting me have by the end of the month is evidently not to narrow down the likely referent, but to remind B of a promise which has not been kept. The reminder seems to work equally well in either of the suggested tonality treatments.

\section{ASSESSING RULES FOR TONICITY}

Probably more has been written about tonicity (especially the selection of the nuclear accent location) than about any other aspect of English intonation. Among the principles most widely mentioned are:

1. A 'general tendency for the nucleus to be towards the end of the IP' (Wells 2006: 95), specifically 'within the last lexical item in the intonation unit' (Tench 1997: 56), a rule which has been claimed to account for more than $80 \%$ of nucleus placements (depending on the precise nature of the material considered).

2. A preference for certain parts of speech, specifically favouring content words over function words, and nouns over other classes of content word, such as verbs (Wells 2006: 97-99; 170). Successful implementation of this as a 'rule' relies on establishing agreement over the relevant classes.

3. The deaccenting of 'old' or 'given' information (Wells 2006: 109 etc.) repeated at the end of an IP, resulting in a leftward shift of the nucleus, seen in such examples as D'you object to dogs?-No, I a dore dogs.

4. The marking of so-called contrastive stress - variously also called contrastive focus or narrow focus (Wells 2006: $119 \mathrm{ff}$; Tench 1996: 60). This is allowed to override other principles, resulting for instance in the accenting of function words in such examples as I can send a fax V to him, | but I can't receive one |from him. |

If we now attempt to match the tonicity choices which were actually made against the principles that supposedly guide them, numerous difficulties are revealed.

The problems begin in the first line of the dialogue. Supposing the tonality choice to be made (as discussed above) in favour of a single IP, why is the nucleus then not straightforwardly placed on the last content word of the whole IP, i.e. month, in accordance with the most basic rule of all (Wells 2006: 95; Tench 1996: 56)? 
Indeed, a nucleus can be placed on month, but only if the nucleus on newsletter is also retained, with the consequent division into two IPs. This was the version anticipated by $E$ when the passage was devised:

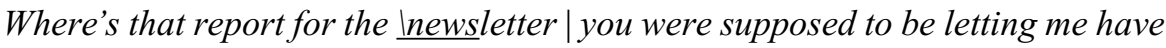
by the end of the $\underline{\text { month}}$ ?

Comparison of the two treatments - which are both acceptable - suggests that the nucleus on newsletter is felt to be obligatory, while the nucleus on month is optional. So it would be pointless to attempt to justify the relatively early nucleus on newsletter as resulting merely from the deaccenting of what follows (Wells 2006: 109). Evidently, it is positively required that newsletter be in focus, regardless of what follows, and regardless of the prosodic treatment of that following material. We are not able to identify any principle, or combination of principles, which will lead to this result.

The rules similarly fail to predict why the nucleus is not simply placed on the last word in each of the following

- but I've only got a bit of final editing to do

- what's the use of having half a ton of stainless steel world-time chronometer strapped round your wrist

- if it doesn't know how many days there are in the month

In the case of and it is only breakfast time the observed tonicity does appear to accord with the principles, but specific lexical knowledge is needed to confirm that breakfast time is a compound noun (contrast breakfast television).

There is also at least one place where there is a danger of over-generalization (hypercorrection). Assignment of the correct tonicity in the IP stop fiddling with the stupid thing depends on recognising that the stupid thing is 'empty' and hence unaccented (Wells 2006: 150). How is the learner to know that the same principle does not apply in Good point? After all, he or she will have encountered phrases such as nice one, good one, and point is commonly encountered unaccented, as in one of her good points. Again, guidance must come from the dictionary rather than the intonation handbook. There can be fewer more discouraging experiences for a learner than the careful application of a 'rule' which results in a wrong output.

\section{ASSESSING RULES FOR TONE}

It will not be a surprise that, as was the case with tonality and tonicity, the degree of agreement over the choices of tones is greater than would appear to follow from known 'rules' governing tone choice. In B's first utterance, for example, the three judges were unanimous in using the fall-rise nuclear tone in all three IPs:

Well, admittedly today's the $3 \bigvee / \underline{1 s t}$, | but I've only got a bit of final Vediting to do $\mid$ - and it is only V breakfast time. 
The speaker is perceived as making limited concessions (admittedly ... only ... only) while at the same time appealing to A to be reasonable.

But probably it would be too much to claim that one of the 'uses' of the fall-rise is specifically 'in concessions which are designed to persuade' or something of the sort (cf. Maidment 1990: 19). Perhaps the most we might claim is that the fall-rise carries the 'implication' (Wells 2006: 27) that the hearer must look for an interpretation beyond the simple literal one. On the other hand, Kingdon's characterisation of the meaning of the fall-rise appears to come close to the meaning of the present examples: '[it] gives the impression that the speaker wishes to convey some insinuation in making the statement, expecting his hearer to understand more than is said ... It is the natural tone for giving a warning or offering an apology' (1958: 29-30).

\section{CONCLUSIONS}

In this paper we have repeatedly called into question effectiveness of 'rules' concerning English intonation. Widely varying relative weight has been placed at different times on practice drill material and rule-based exercises. This is seen, for example, by comparing the largely drill-based material of O'Connor and Arnold (1973) with the rule-based problem solving favoured by Wells (2006).

By examining intonation notations provided by expert judges for a typical test passage designed for advanced students, we have shown that 'rules' seem to account only for a proportion of the 'right' or expected answers (if the 'right' answers are taken to be those represented by a consensus of native speaker judgments). There are plentiful instances where native speakers agree over the selection of a pattern, though no known rule seems to guide their choice. No doubt in certain cases they are merely following habitual idiomatic patterns (cf. Ashby 2006), but in others the native speakers may be following 'rules' much more complex and nuanced than those which find their way into intonation handbooks, and hitherto covert lexical, grammatical, semantic or pragmatic categories may be at work. It is doubtful whether these can be rendered accessible to the learner.

The morals for the teaching of intonation would seem to be:

(1) Before teaching a 'rule' and reinforcing it with (often artificial) examples we should consider not only the satisfying explanatory power it seems to have in those cases to which it applies, but also the actual frequency with which it is likely to be used, and the potential harm it can do if overgeneralised.

(2) Due attention must be given to the idiosyncratic accentual behaviour and prosodic patterns of particular lexical items and 'fixed expressions'. Paradoxical as it may seem, a good learner's dictionary is an important tool in the learning of intonation.

(3) We must as a first priority provide learners with practical heuristics which can be applied quickly and which lead to intelligible default realizations (for example, in reading aloud, divide into IPs by following the punctuation, accent the last word in the IP, use a fall at sentence-end and non-fall between clauses). Such advice is conspicuously missing from intonation handbooks. No doubt the 
authors of such works feel obliged to advance respectable linguistic arguments, and practical heuristics are not easily cast in 'linguistic' terms. In this, we have something to learn from the humble prescriptions to be found in long-outdated elocution and spelling books. We conclude with an example from Fowle (1829), and pose the question whether the terminological and methodological complexities of - say - Wells (2006) or Tench (1996) bring the learner any real advantage.

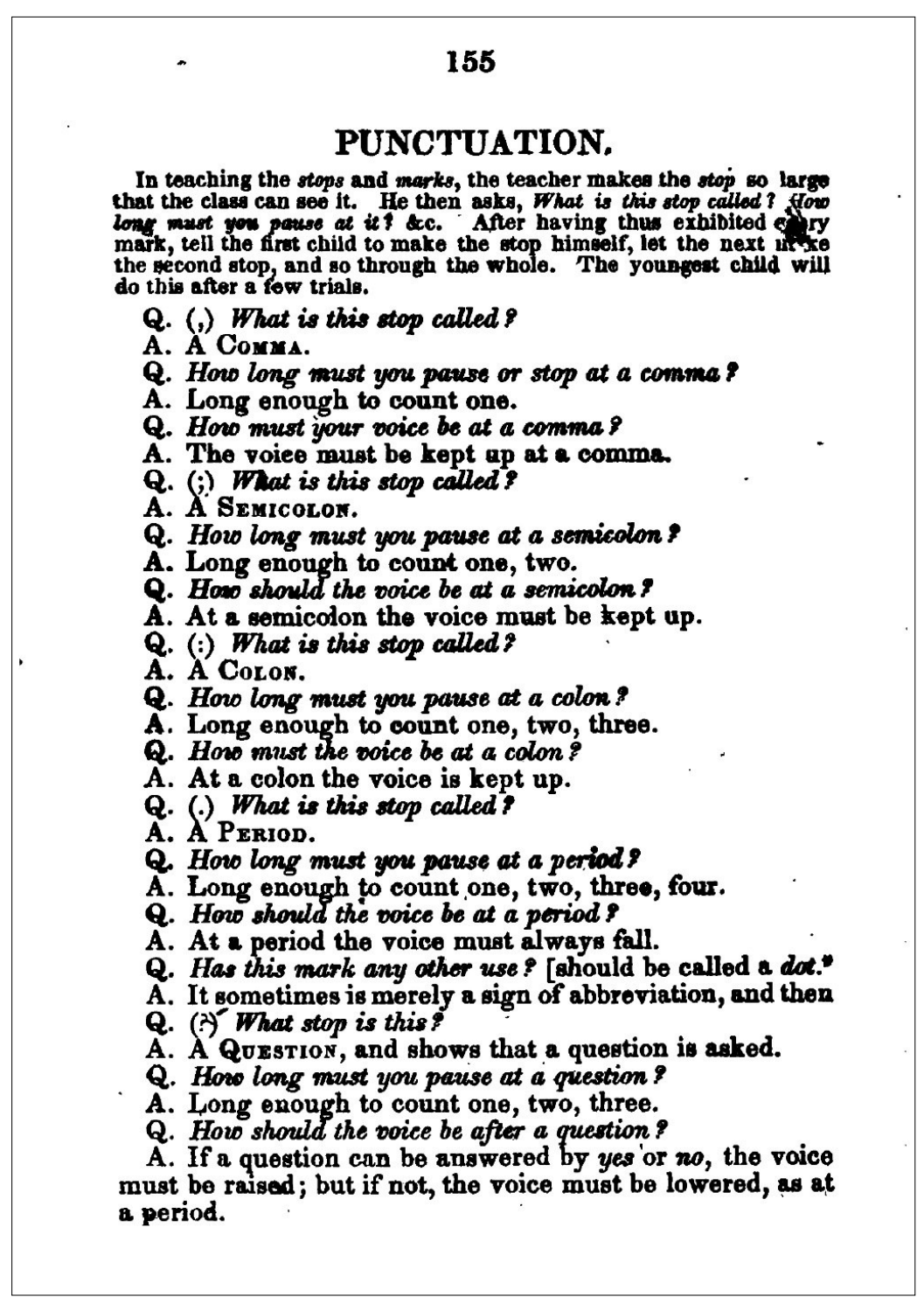

Figure 1: A page from Fowle (1829) 


\section{References}

ALTENBERG, Bengt (1987) Prosodic patterns in spoken English : studies in the correlation between prosody and grammar for text-to-speech conversion. Lund: Lund University Press.

ASHBY, Michael (2006) "Prosody and idioms in English." Journal of Pragmatics 38/10, 1580-1597. http://dx.doi.org/10.1016/j.pragma.2005.03.018

CRUTTENDEN, Alan (1991) "Intonation and the comma." Visible Language 25/1, 54-73.

CRYSTAL, David (1975) The English tone of voice: Essays in intonation, prosody and paralanguage. London: Edward Arnold.

FOWLE, William Bentley (1829) The improved guide to English spelling, etc. Boston, Mass.: Hillard, Gray, Little \& Wilkins.

HOUSE, Jill (1987) "Review of Altenberg (1987)." Computer Speech and Language 2/2, 364-367.

HUDDLESTON, Rodney/Geoffrey K. PULLUM (2005) A student's introduction to English grammar. Cambridge, UK/New York: Cambridge University Press.

KINGDON, Roger (1958) The groundwork of English intonation. London: Longmans, Green.

MAIDMENT, John A (1990) "Focus and tone in English intonation.” In: S. Ramsaran (ed.), Studies in the pronunciation of English. London: Routledge, 19-26.

O'CONNOR, J. D/G. F ARNOLD (1973) Intonation of colloquial English. A practical handbook. $2^{\text {nd }}$ ed. London: Longman.

TENCH, Paul (1996) The intonation systems of English. London/New York: Cassell. WELLS, J. C. (2006) English intonation: An introduction. Cambridge: Cambridge University Press.

\section{Abstract \\ UNRULY INTONATION}

In this paper we call into question the value of 'rules' concerning intonation to the learner of English. Are there predictive rules of sufficient generality and power to make them worth learning explicitly, or would learners' time be better spent on habit-forming drills of common patterns? Examining a typical test passage for advanced students, we show that in all three systems of tonality, tonicity and tone, known 'rules' account only for a proportion of the 'right' or expected answers. There are plentiful instances where competent native speakers agree over the selection of a pattern, though no rule seems to guide their choice. We recommend that the utility of 'rules' should be evaluated in relation to the frequency of occurrence of the structures to which they apply, in the relevant types of discourse; that more attention be given to idiomatic expressions, and the prosodic patterns associated with particular lexical items; and that learners should be equipped with simple practical heuristics (e.g. for using punctuation as a guide to intonation when reading aloud).

Keywords: English intonation, applied phonetics, tonality, tonicity, tone 


\section{Povzetek \\ NEUKROTLJIVA INTONACIJA}

Članek kritično presoja pomen intonacijskih pravil za učence angleščine. Ali obstajajo predvidljiva pravila, ki so dovolj splošna in močna, da bi se jih veljalo naučiti? Ali bi morda ne bilo časovno bolj učinkovito uriti splošno veljavne intonacijske vzorce? Na primeru testnega besedila za napredne študente bomo pokazali, da pravila za določanje tonalnosti, toničnosti in tonskih potekov lahko razložijo samo nekaj pravilnih oziroma pričakovanih odgovorov. Obstaja veliko primerov, kjer se kompetentni rojeni govorci strinjajo glede izbranega intonacijskega vzorca, čeprav ni nobenega pravila, ki bi utemeljeval izbor tega vzorca. Zato predlagamo, da se uporabnost pravil oceni glede na pogostost pojavljanja struktur, na katere se pravila nanašajo, upoštevaje ustrezne diskurze; da se posveti več pozornosti intonacijskim vzorcem v idiomatskih izrazih in določenih leksikalnih enotah; ter da se učencem predstavi preproste in praktične smernice (npr. upoštevanje ločil pri glasnem branju intonacije).

Ključne besede: angleška intonacija, uporabna fonetika, tonalnost, toničnost, ton 


\section{APPENDIX: THE THREE NOTATED VERSIONS}

\section{E's version:}

A: 'Where's that report for the \newsletter | you were supposed to be letting me have by the end of the $\backslash$ month?

B: Well, ad\mittedly today's the $3 \bigvee \underline{1 \text { st }} \mid$ but I've only got a bit of final $\bigvee \underline{\text { editing to }}$ do $\mid$ and it lis only $\bigvee$ breakfast time.

A: The $3 / \underline{1 \text { st? }}$ Of $\bigvee \underline{\text { April? }}$ ?

B: $\underline{\text { Ah }}$ | Good point | I was going by my $\underline{\text { watch } \mid}$

A: What's the use of having half a ton of stainless steel world-time chro $\vee$ nometer strapped round your wrist | if it ldoesn't know how many \days there are in the month?

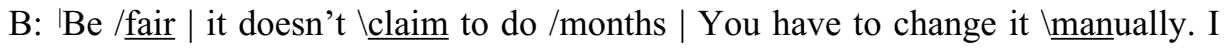
relmembered to do it in $\backslash$ February.

A: I should $\backslash$ hope so | or you'd be half a \week out by /now | \} \text { Anyway | stop } \bigvee \text { fid- }

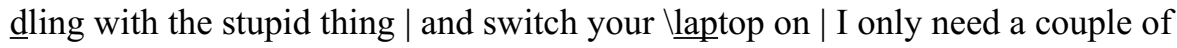
/paragraphs.

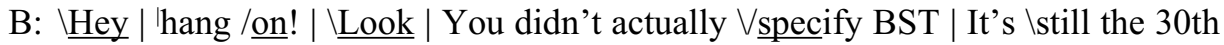
in $\mathrm{A} \bigvee \underline{\text { laska }}$ | and I've got an hour to $\underline{\text { spare }}$

\section{J1's version:}

A: $\{\mathrm{hh}\}$ Where's that report for the \newsletter you were supposed to be letting me have by the end of the month? (That's some tail, huh?)

B: Well, ad $\{\mathrm{fh}\}$ mittedly today's the $3 \mathrm{~V} 1 \mathrm{st}$, | but I've \{fh\}only got a bit of final Vediting to do - and it $\{\mathrm{fh}\}$ is only Vbreakfast time

A: The 3/1st? Of /April? (high rises)

B: \Ah. $\{$ hh $\}$ Good $\backslash$ point. I was $\{\mathrm{hh}\}$ going by my \watch.

A: $\{\mathrm{fh}\}$ What's the use of having half a ton of stainless steel world-time chroVnometer strapped round your wrist $\mid$ if it $\{\mathrm{rh}\}$ doesn't know how many days there are in the \month?

B: $\{\mathrm{fh}\}$ Be Vfair. It doesn't $\backslash$ claim to do months. You $\{$ hh $\}$ have to change it $\backslash$ manually. I re $\{\mathrm{fh}\}$ membered to do it in VFebruary.

A: I should hope $\backslash$ so, $\mid$ or you'd be $\{$ rh $\}$ half a $\backslash$ week out by now. $>$ Anyway, $\mid$ stop |fiddling with the stupid thing | and switch your Vlaptop on. I \{fh\}only need a couple of Vparagraphs.

B: \Hey, $\mid$ hh $\}$ hang /on! \Look! You $\{$ fh $\}$ didn't actually specify BSVT. It's $\{\mathrm{hh}\}$ still the 130 th $\mid$ in AVlaska, and I've got an $\{h$ h $\}$ hour to \spare.

$\{\mathrm{fh}\}=$ falling head

$\{\mathrm{hh}\}=$ high head

$\{\mathrm{rh}\}=$ rising head 


\section{J2's version:}

A: Where's that report for the fall newsletter you were supposed to be letting me have by the end of the month?

B: Well, admittedly today's the $3 f-r 1$ st, | but I've only got a bit of final $f$-rediting to do 1 -and it is only $f-r$ breakfast time.

A: The 3 low rise 1st? | Of high rise April?|

B: fall Ah. | Good fall point. | I was going by my fall watch.

A: What's the use of having half a ton of stainless steel world-time chro $f-r$ nometer strapped round your wrist | if it doesn't know how many fall days there are in the month?|

B: Be low rise fair. | It doesn't claim to $f-r$ do months. | You have to change it high fall manually. | I remembered to do it in $f-r$ February. |

A: I should hope high fall so, | or you'd be half a (rise)-fall week out | by low rise now. | high fall Anyway, | stop $f-r$ fiddling with the stupid thing | and switch your fall laptop on.| I only need a couple of $f-r$ paragraphs. |

B: high fall Hey,| hang low rise on!| high fall Look! |You didn't actually specify BS $f-r$ T. |It's still the high fall 30th | in A $f-r$ laska, | and I've got an hour to (rise)fall spare. 